Bear, C. (2011), Being Angelica? Exploring individual animal geographies. Area, 43: 297304. doi: 10.1111/j.1475-4762.2011.01019.x

Being Angelica? Exploring individual animal geographies

Christopher Bear

Institute of Geography and Earth Sciences, Aberystwyth University, Penglais Campus, Aberystwyth, SY23 3DB, UK

Email: c.bear@aber.ac.uk

The definitive version is available at www.blackwell-synergy.com:

http://onlinelibrary.wiley.com/doi/10.1111/j.1475-4762.2011.01019.x/abstract 
Bear, C. (2011), Being Angelica? Exploring individual animal geographies. Area, 43: 297304. doi: 10.1111/j.1475-4762.2011.01019.x

\title{
Being Angelica? Exploring individual animal geographies
}

\begin{abstract}
This paper extends recent work that has called for greater attention to be paid to nonhuman difference. The burgeoning animal geographies literature has been very successful in dissecting the concept of 'nature' and in examining the myriad ways in which animal and human lives are intertwined. However, its focus is more often on collectivities, such as species and herds, than on individual animals. Through the brief case study of an octopus in The Deep, an aquarium in Kingston-upon-Hull, UK, the paper draws on and develops recently-promoted notions of responsible anthropomorphism. It argues that future work might usefully pay greater attention to the lived experience of individual animals, and that further emphasis should be given to non-mammalian life forms. Doing so might not only shed light on these creatures' encounters with humans but also help to give a greater sense of their lives beyond these direct encounters, challenging understandings of what it means to be 'animal'.
\end{abstract}

\section{Key words}

Animal geographies; individual animals; anthropomorphism; nonhuman difference; octopus; Kingston-upon-Hull, UK 
Bear, C. (2011), Being Angelica? Exploring individual animal geographies. Area, 43: 297304. doi: 10.1111/j.1475-4762.2011.01019.x

\section{Introduction}

On entering a darkened room, a soundtrack plays, speaking of 'a world too deep for sunlight to reach, a place of endless night, of weird and alien life forms, a place so hostile few dare to venture' (research notes, February 2006). Moving to the next room, we come face-to-face with these weird and alien life forms, some barely visible through the darkness. This is the Twilight Zone, part of The Deep, an aquarium in Kingston-upon-Hull, UK. This paper is about one of the 'alien life forms' in particular - a giant Pacific octopus which, I am told on my first visit, is called Angelica.

Through its focus on Angelica, the paper responds to calls to give a greater sense of animals as animals (Philo and Wilbert 2000; Holloway 2007), to tease apart nonhuman difference and more closely interrogate the diversity of animal life (Bear and Eden 2011; Davies 2008; Lulka 2009; Whatmore 2005). The paper critiques animal geographers' tendency to speak of collectivities such as 'animals', 'species' and 'herds', while speaking less of individual creatures. In spite of a turn to studies of animal lifeworlds and subjectivities - attempts to move away from an anthropocentric perspective - researchers have been largely silent on individual animals, excepting those kept as pets (Power 2008; Fox 2006), or as domestic livestock (Holloway 2001).

This paper uses the example of Angelica to engage with these issues and argue for: 1) more attention to be paid to the lived experiences of individual animals; and 2) a greater focus on cold-blooded animals in non-airy spaces. Angelica's confined situation in the aquarium makes some aspects of her story easy (in relative terms) to tell. However, the issues raised 
Bear, C. (2011), Being Angelica? Exploring individual animal geographies. Area, 43: 297304. doi: 10.1111/j.1475-4762.2011.01019.x

here offer significant challenges for future research investigating the lived experiences of animals in a variety of contexts. The paper's originality lies in focusing on a single octopus and her actions, her representation, and her involvement in affective relationships that transgress species boundaries. Its purpose is to highlight the types of observations that might help develop a less anthropocentric animal geography.

The paper proceeds by introducing the context of The Deep, before giving a more thorough critical review of the animal geographies literature. In the fourth section, the life of The Deep's octopus(es) is/are explored prior to a conclusion that considers some of the methodological and ontological challenges that studies of individuals might pose.

\section{The Deep}

Hull's aquarium, The Deep, opened in 2002. Originally costing around $£ 52$ million, over half of this cost was met by the UK's Millennium Commission and the European Regional Development Fund (ERDF) (The Deep date unknown). Designed to regenerate a derelict area of the city, it had been attended by over two million visitors by the end of 2009 (Yorkshire Forward date unknown). Whilst being a tourist attraction, it also has a dedicated education programme, attracting 30,000 school pupils every year (The Deep date unknown). Its stated aim is 'to create a deeper understanding of the world's oceans' (Brown 2008, 1). 'The Twilight Zone' was added in 2005, part of a second phase of development costing $f 6.8$ million and funded by the Millennium Commission, ERDF, Citybuild and the Deep itself (The Deep date unknown). Its purpose is to display a new range of animals, including Japanese spider crabs, wolf eels, flashlightfish, nautilus and, the 
Bear, C. (2011), Being Angelica? Exploring individual animal geographies. Area, 43: 297304. doi: 10.1111/j.1475-4762.2011.01019.x

subject of this paper, the giant Pacific octopus. These species are united by the depth of their habitat - 200-1000m below the ocean surface - but are largely separated from each other by the walls between tanks. A spacious room, the Twilight Zone is dimly lit in purple and blue, with tanks around its perimeter. Each tank, visible to visitors only through its front panel, is accompanied by brief explanations of its contents, giving the common and Latin names of its inhabitant species, along with information on their geographic origins and ecological health. No information is given on the specific individual in these written explanations.

Walking through, it becomes apparent that the weird and alien life forms are of great interest to many of the visitors, and are spoken of enthusiastically by the staff. While ostensibly alien in bodily form, there is clearly much to be said about these creatures, both from a scientific perspective and by the guides who work with and feed the animals. Angelica, as evidenced by the frequent placement of a guide by the occupant's tank, is the Zone's star attraction.

This paper stems from visiting The Deep between 2006-2008, during which time I became interested not only in how Angelica was presented to visitors but also how she lived her own life. Her presentation does not only involve formal information displays but stories told by the Deep's staff about her everyday life, along with her own actions. I argue that by attending to such multiple stories we might begin to further include the lives and subjectivities of individual non-humans in work on hybrid geographies. Recent work has encouraged a questioning of the relationship between species and individuals but I take 
Bear, C. (2011), Being Angelica? Exploring individual animal geographies. Area, 43: 297304. doi: 10.1111/j.1475-4762.2011.01019.x

this further by looking at the shifting and contested identities of a single creature. I am influenced by Johnston's (2008) approach of 'responsible anthropomorphism' but also follow Lorimer's $(2005,497)$ call to combine ethnographic with ethological approaches (in his case, from listening to 'retold stories' [p. 502]). I review existing literature on animal studies and animal geographies in the next section.

\section{Towards a re-animated animal geography}

Following Wolch and Emel's (1995) seminal paper, there has been a burgeoning literature on the so-called 'new' animal geography (Philo 1995). The central concern of this work is that human geographers had treated animals as little more than a background to human society, reinforcing dualisms of nature and culture. Inspired by the symmetrical ontologies of actor-network theory (Latour 1993), animal geographers have attempted to dissect these dichotomies, examining how the lives of animals are coconstitutive of family life (Power, 2008; Fox 2006), capitalist production (Ufkes 1998) and recreational practice (Ryan 2000). They have also shown the ways in which animals have been deliberately excluded from certain spaces (Philo 1995), demonstrating the analytical advantages of reimagining 'society' through a hybrid ontology.

Through this common theme of a heterogeneous society some authors have chosen to focus on representations of animals (Woods 2000) but, more recently, animals' affective agency has been foregrounded, prompted by calls to 'find a way of thinking...that grants them positive ontological difference in their own right' (Bingham 2006, 492). As such, one strand of literature moves away from the idea that animals might best be understood as 
Bear, C. (2011), Being Angelica? Exploring individual animal geographies. Area, 43: 297304. doi: 10.1111/j.1475-4762.2011.01019.x

'strange persons' (Whatmore and Thorne 1998). Others (Johnston 2008) argue that, inasmuch as it is impossible to develop truly symmetrical studies involving both humans and nonhumans, a more critically anthropomorphic approach might usefully be developed. A commonality of these perspectives is to heighten the problem of 'the animal'. Whether led by cultural geography's interest in individual difference, an anthropomorphic approach or an ontological concern with defining society, the stability and utility of the category 'animal' appears increasingly untenable.

At its most extreme (and even in its very name) animal geographies - and related work in philosophy (Midgeley 1983) and anthropology (Ingold 1994) - has a tendency to refer to 'animals' as a distinct group, blurring differences not only between animals of different species but also of the same species (see Derrida [2002] for the now classic deconstruction of this issue). The problem has recently been highlighted by Lulka (2009), Davies (2008) and Philo (2005), who have all called for greater attention to be paid to nonhuman difference. The focus of recent work has thus shifted to the shared and co-constitutive practices of more-than-human relationships, giving a greater sense of subjectivities and everyday lives.

Examples of such research include Holloway (2007), who examines how cows learn about, and adapt to, new milking technologies, exploring the notion of bovine subjectivities, and Hinchliffe et al (2005), who attempt to understand water voles in their own terms, by 'reading' their 'writing' - following their footprints and droppings. While such studies problematise simplistic divisions between 'humans' and 'animals', the place of the individual remains ambiguous. Although Hinchliffe et al (2005) followed individual vole 
Bear, C. (2011), Being Angelica? Exploring individual animal geographies. Area, 43: 297304. doi: 10.1111/j.1475-4762.2011.01019.x

trails, these were often aggregated in discussions of 'water voles'. Here, a tension develops between species and more-than-species approaches, where the centrality of individuals becomes muddied. While Hinchliffe et al propose one means by which the 'voices' of animals might be brought into social science studies, the animals often remain quite twodimensional (though affective, active and agential) - indeed, in that particular piece of work, the water voles themselves were in many ways absent.

The study of individual animals is not without precedence, but has been more common in popular fiction and film, which have often used animals either as a focus for wider stories (e.g. Gavin Maxwell's [1960] Ring of Bright Water), or in anthropomorphic form (e.g. Disney's [1941] film Dumbo). It is perhaps in part because of such anthropomorphisms that geographers have remained cautious about producing ostensibly similar stories themselves (see Johnston 2008, 640; Lorimer 2010). Other authors have adopted biographical approaches to explore their relationship with pets (e.g. John Grogan's [2005] Marley and Me), or with animals that are intended for human consumption as food (Lovenheim 2003). Fewer academic studies have attempted such approaches, although notable exceptions include Sanders's (2006) discussion of police dogs as 'objects' and 'individuals', and Shapiro's (1997) study of his own dog. Most relevant here are two papers that explore different 'becomings' of non-humans: elephants (Whatmore and Thorne 2000) and fish (Bear and Eden 2011). In the former, different 'becomings' of elephant are investigated. Focusing on Duchess, an elephant at Paignton Zoo, and her experiences of moving to a new enclosure that aimed to mimic her home habitat of African savannah, Whatmore and Thorne highlight the difference between taxonomic status and lived being, where 'her life 
Bear, C. (2011), Being Angelica? Exploring individual animal geographies. Area, 43: 297304. doi: 10.1111/j.1475-4762.2011.01019.x

at Paignton Zoo bears only distant relation to those of her kind at home in the African bush' (p. 194). While their paper dealt broadly with the variety of ways 'elephant' circulates as category, written text and lived being, their focus on an individual living creature particularly distinguished this from other work, and drew greater attention to the relationship between individual and species. However, Philo (2005, 829, original emphasis), commenting on Whatmore's (2002) writings on elephants, observed that:

'the animals-in detail, up close, face-to-face, as it were-still remain somewhat shadowy presences[.] They are animating the stories being told, but in their individuality - as different species, even as individuals - they stay in the margins'.

Bear and Eden's (2011) paper, meanwhile, responded to work that has suggested fish are 'alien' to humans because of their cold blood, scaly bodies and non-airy habitat (e.g. Jones 2000, Scruton 1996 and Mullan and Marvin 1987). The paper demonstrated that anglers do not merely target 'fish' but think of them and interact with them through a complex variety of aggregations and individualisations, and that the individual fish are active (if not willing) participants in angling. Mullan and Marvin's (1987, 73-74) contention that 'fish are completely "other", and live in a totally alien environment' was thus rendered highly problematic, and an overly simplistic way of categorising human/non-human relationships.

While this paper is about cephalopods, rather than fish, it is addressing similar issues, in exploring how non-airy spaces, cold blood and very 'other' bodily forms do not act as barriers to inter-species affective encounters. Extending Whatmore and Thorne's 
Bear, C. (2011), Being Angelica? Exploring individual animal geographies. Area, 43: 297304. doi: 10.1111/j.1475-4762.2011.01019.x

arguments, my intention is to move an individual animal from the margins, looking not only at how this is represented, but at how it presents itself, lives a life outside of these (re)presentations and at how humans have responded. I show that this can be a tricky task even in the controlled and bounded space of an aquarium, where the nature and status of the animal in question is ambiguous, both through life and after death.

\section{Angelica}

This section presents brief vignettes relating to different aspects of Angelica's life in The Deep, covering themes of representation, agency and selfhood. The vignettes are drawn from ethnographic observations made between 2006-8, including informal conversations with the aquarium attendants and guides.

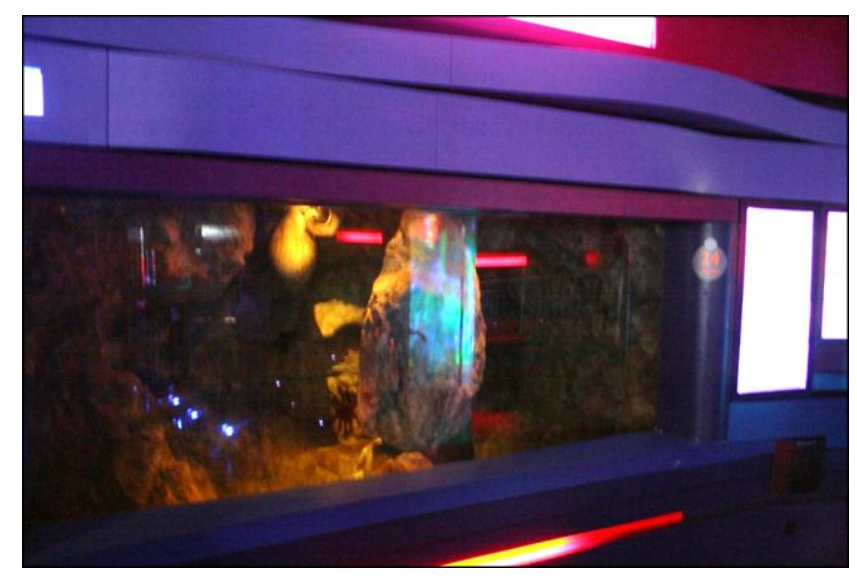

Plate 1 The Deep's giant Pacific octopus tank

\section{Source: author}

She's very calm and still today. Wedged into a crevice at the back. Very similar to the last time I came - little movement, almost invisible, could easily be mistaken for a rock until your eyes adjust to the light and notice the breathing. A boy next to me 
Bear, C. (2011), Being Angelica? Exploring individual animal geographies. Area, 43: 297304. doi: 10.1111/j.1475-4762.2011.01019.x

- about eight years old - told his mother 'the octopus is boring; I like sharks better'. His mother asked the attendant 'does it get lonely in there by itself?' The attendant told her that they keep her entertained by hiding her food in tubes that she has to squeeze through to locate it and said that 'we don't breed them here because they're likely to eat each other'. The boy tried getting Angelica's attention, pressing his fingers on the glass and jumping up and down, but she was either oblivious to or unmoved by this. (Research notes, January 2006)

Arriving at the second tank in the Twilight Zone (Plate 1), there appears to be no movement for the majority of time. Once one's eyes accustom to the virtually dark tank, what first appeared to be a rock is contracting and expanding. This is a living creature. We also know that it is a living creature because of the information prominently displayed on the tank side (Plate 2): the creature is a giant Pacific octopus (Enteroctopus dofleini), which would normally live at depths of up to $250 \mathrm{~m}$ during the day, sheltering 'under rocks or in crevices', coming out at night to 'hunt for shellfish'. It is generally found not in Hull but in the Northern Pacific Ocean, where we are told 'these giants' are protected by fishery regulations. 
Bear, C. (2011), Being Angelica? Exploring individual animal geographies. Area, 43: 297304. doi: 10.1111/j.1475-4762.2011.01019.x

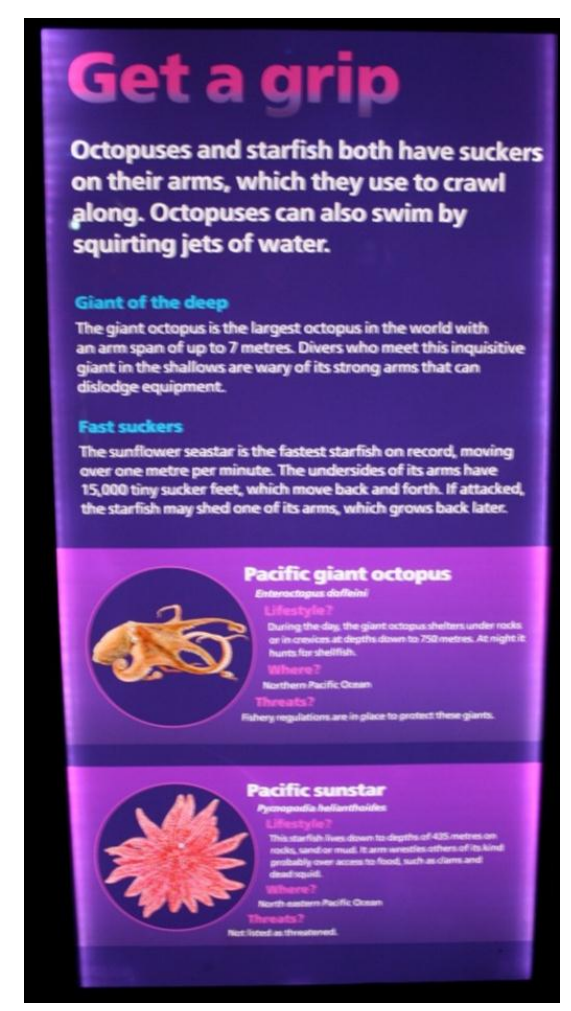

Plate 2 Explanatory light box at the side of the octopus tank

Source: author

This résumé on the tank side could easily be dismissed as being almost irrelevant to this displaced being that is on view (see also Whatmore and Thorne 2000, 194; Malamud 1998, 1). Being a giant Pacific octopus is much like being 'a human' - a number of beings with similar characteristics but which are nonetheless significantly different from each other. Ostensibly, the octopus is here as a representative of its species. However, this is not just a giant Pacific octopus; this is Angelica (Plate 3). 
Bear, C. (2011), Being Angelica? Exploring individual animal geographies. Area, 43: 297304. doi: 10.1111/j.1475-4762.2011.01019.x

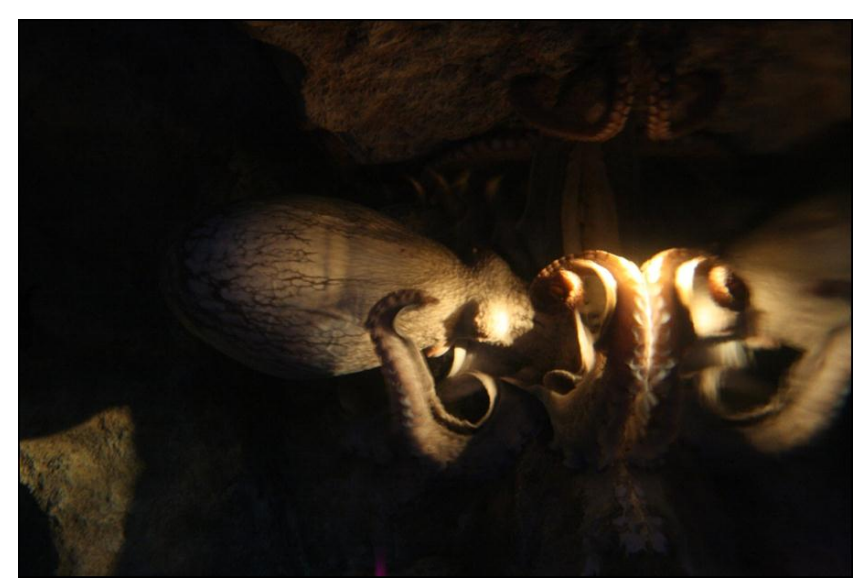

Plate 3 Angelica

\section{Source: author}

Angelica was donated to The Deep, having been caught as by-catch by a trawler off the California coast (a common means by which aquaria build their collections [CAPS 2004, 6], though ironic given the tank-side focus on protection through fishery regulation). The name 'Angelica' serves as a clue to some of the experiences of this being and of the relationships it has with those around it. The name comes from a children's cartoon, Rugrats, in which Angelica is, as one Deep guide put it, 'spoilt with too many toys'. This analogy helps to explain some of the relationships that are taking place here, but also sheds light on Angelica's own requirements and actions. Her naming suggests a pet-like view from those who look after her, but the choice of name also reflects her own demands and actions; she is not just an octopus but a being with whom those who work in the Deep develop very particular relationships. Malamud $(1998,2)$ argues that 'people cannot appreciate an animal's essence when it is displayed in captivity alongside a hundred others with which it does not naturally share living quarters, in an artificial compound that they pay to enter'. Sorenson $(2008,204)$ similarly argues that captive animals are not seen as 'individuals with their own subjectivity' and are instead 'turned into mere objects', but this 
Bear, C. (2011), Being Angelica? Exploring individual animal geographies. Area, 43: 297304. doi: 10.1111/j.1475-4762.2011.01019.x

is to simplify the relationships being played out here. While she is inarguably confined and this significantly impacts on the way she might express herself and act, this should not be to deny her subjectivity; animals become with their environments and those around them (Haraway 2008) and to argue that a captive animal is any less for being captive is only to further objectify it.

About 15 people gathered around the tank today when I arrived. I hadn't seen this before - she was really throwing herself around the tank. Quite violently. Had apparently been doing it for about an hour when I arrived, maybe resting every few minutes before re-starting. Some people thought it was amazing; others were concerned she would hurt herself. The guide said it was nothing to worry about she just wants food. She told us that they had fed her in the past when this happened to prevent her injuring herself and that Angelica seemed to have learnt that if she did it for long enough, she would be fed. About ten minutes after I arrived, she stopped and settled down at the back of the tank. (Research notes, February 2006)

Angelica's requirement for 'too many toys' becomes apparent through further conversation with Deep guides, one of whom stated that 'octopuses have the same level of intelligence as a dog or cat' (cf Bingham 2006, 492) and, therefore, require some form of entertainment when in such a confined space. Various tactics are used. Food is sometimes placed inside a system of tubes through which she must squeeze in order to eat; at other times food is contained inside a Mr Potato Head, which she must demolish to eat - 
Bear, C. (2011), Being Angelica? Exploring individual animal geographies. Area, 43: 297304. doi: 10.1111/j.1475-4762.2011.01019.x

'enrichment' tactics that are on view to the visiting public (although not at advertised 'show' times as is often found in zoos and aquaria). Here, we see scientific and everyday stories about Angelica and her species coming together with her own actions: understandings of the intelligence of a species, attempts to feed (both literally and metaphorically) this determined level of intelligence, and her own requests for food.

To this point, it appears that, since moving to Hull, Angelica has lived a very controlled, confined life. This is certainly the impression conveyed by the information around the tank, and by the physical boundaries of the tank itself. However, Angelica's agency becomes apparent when speaking to the Deep's guides. A favourite story to tell is of Angelica's first few weeks in Hull, when staff were mystified as to what had eaten the emperor nautilus in the next tank. A member of staff arrived one morning to witness Angelica returning to her tank, having climbed over the wall, into the next tank and consumed another of these shellfish. One might draw parallels here with the tank's information about octopus behaviour where, at night, they come out of their shelter and search for shellfish. Angelica can be seen to express her subjectivity, irrespective of the barriers that appear to surround her (though this is not to romanticize her confinement; a gauze lid was placed on her tank to prevent repetition). Her ability to express aspects of her subjectivity continued in other ways, such as her partial ability to determine her feeding times.

Again, little movement in the tank today, though she is very visible sitting at the front, so there are quite a few people watching her. A girl - probably about five years old - comes over to the tank saying 'wow, it's so much bigger than the last 
Bear, C. (2011), Being Angelica? Exploring individual animal geographies. Area, 43: 297304. doi: 10.1111/j.1475-4762.2011.01019.x

time'. Her parents aren't so sure. Another set of parents, who've been standing there for about five minutes, comment that their son, who looks about the same age, always wants to see the octopus after watching it feed once - but that it's never been moving when they've visited since. I asked both families if they visit often; they all have season tickets and the children always want to make a bee-line for the sharks and the octopus. (Research notes, February 2006)

While the descriptions around the tank do not give any sense of this individuality, an attendant confirmed that it is far from unusual for Deep season ticket holders to make visits specifically in the hope of witnessing one of Angelica's more outwardly active periods. Far from being an alien life form in an alien space, as Jones (2000), Scruton (1996) or even the soundtrack at the entry to the Twilight Zone might suggest, this octopus is of interest as an individual with whom people attempt to relate.

To this point, I have shown some of the ways this octopus is represented, engages humans through her own actions and also expresses her own subjectivity through demands for food and the (subsequently disciplined) exploration of her surroundings. Looking at this variety of aspects of Angelica's existence begins (indeed, only begins) to give a sense of the wholeness of this individual's life - a subject to which I return in the final section

Some months after my first visit to the Deep, a colleague informed me that Angelica had died. Concerned, I phoned the Deep, where the receptionist asserted that she thought Angelica was alive, but that she would check; she returned to say that 'she's alive and 
Bear, C. (2011), Being Angelica? Exploring individual animal geographies. Area, 43: 297304. doi: 10.1111/j.1475-4762.2011.01019.x

kicking'. A few weeks later, visiting again, I checked with the guide as to how long this octopus had been in the Deep; Angelica had, indeed, died and had quickly been replaced, unknown to the receptionist. This in itself is only of passing interest. More significant is what it tells us about the notability of Angelica's individuality for those around her. Having given this individuality greater emphasis to this point, we are brought full circle and the creature seems, once again, to be there as a species representative. Indeed, on asking a guide if the new octopus had been given a name, the attendant responded that 'it's not worth giving them a name; they don't live long enough' (Research notes, July 2006). This may be read as the transience of the species representative - one that might easily be replaced and whose individuality matters little to those around it. Equally, it might suggest greater agency for the creature, which is not reduced to a name. The same attendant spoke of how this octopus 'can develop horns when he's in a mood. But I'm still not sure how to interpret these moods' (Research notes, July 2006). He wanted a sense of the individual, to tune into its habits and emotions, but had not yet found a way to do this.

\section{Conclusions}

In this paper, I have suggested that animal geographers should take individual animals seriously, as part of their ongoing project of studying the intertwining of human and nonhuman lives. Much of the existing work in this area has emphasised the co-production of animal and human lives, but has often focused on moments of encounter, whether through active management practices or on the place of pets in family life. Some aspects of the stories illustrated here rely on 'learning to be affected' (Lorimer 2010, 243) by Angelica and her replacement - their attendants' discussions of learning to respond to her actions, for 
Bear, C. (2011), Being Angelica? Exploring individual animal geographies. Area, 43: 297304. doi: 10.1111/j.1475-4762.2011.01019.x

instance. This reflects the 'responsible anthropomorphism' advocated by Johnston (2008, 645), 'attending more closely to understandings of nonhumans garnered from the practice and experience of co-relationality'. This approach encourages the exploration of relations that inform and are revealed through moments of encounter. The primary implications of this are twofold.

First, the nature of these encounters demonstrates the possibility of opening up 'animal geographies' to a greater range of environments and bodily forms. Contrary to the contentions of Jones (2000), Mullan and Marvin (1987) and Scruton (1996), water does not constitute an environment that is 'totally alien' to humans, and the bodily composition of creatures such as octopuses does not negate the possibility of inter-species affective encounters. This is not to say that these encounters are easy, either in practice or in interpretation, but that they should not be situated outside geographers' concerns.

Second, other aspects of the stories here relied on moments beyond direct encounter. Similarities here are closest to Hinchliffe et al's (2005) study of water voles where the authors developed particular senses of these creatures not through direct encounter but with a sensitivity to the traces they left (in the form of footprints and faeces). Both of these studies begin to give a sense of the lives of particular voles and octopuses away from direct encounters (though frequently still bound up in relationships with humans). For Johnston $(2008,646)$, the animal geographies project seeks 'to make nonhumans visible in order to ensure that their material (and in some cases, emotional) needs are not unthinkingly ignored or automatically placed below our own'. While her responsible anthropomorphism 
Bear, C. (2011), Being Angelica? Exploring individual animal geographies. Area, 43: 297304. doi: 10.1111/j.1475-4762.2011.01019.x

is an important move in this direction, there is a danger of leaving lives beyond direct encounter invisible - especially, it might be argued, when these lives are lived in spaces away from direct human gaze, such as in the deep ocean.

In some ways, my choice of Angelica as the focus of this paper was the easy option. Thinking about (and interacting with) the life of an octopus in captivity is notably less complicated than engaging with its ocean-dwelling counterparts. In extending a study such as this to the ocean depths, human geographers lag behind colleagues in the natural sciences, who already tag fish and ring birds to track their paths and learn more of their everyday individual habits (see Mather [1995, 344] for an example of individual octopus tracking in Bermuda). Our increasingly re-defined role as 'more-than-human' geographers might usefully be interpreted as integrators of the different understandings that exist of animals - understandings that tell us something of the animals themselves, whether by speaking to those who track and hunt them (hunters and anglers), those who observe them for pleasure (bird watchers, naturalists), by engaging with scientific practice and literature (animal tracking and animal psychology) or by spending time with the animals themselves. Animal geographers have often been highly reticent to engage in collaborations with natural scientists, other than in studying their practices. This reticence is rooted in the desire to move beyond essentialised representations (Philo and Wilbert 2000) and a critique of animal behaviour studies that points to their inherent partiality and the impossibility of truly knowing what non-human animals are thinking (Malamud 2007, xi). However, having developed more nuanced approaches, the time for more creative interdisciplinary collaborations is ripe. 
Bear, C. (2011), Being Angelica? Exploring individual animal geographies. Area, 43: 297304. doi: 10.1111/j.1475-4762.2011.01019.x

If the extension of work in animal geographies to a wider range of bodily forms and habitats provides new challenges for empirical research, it also holds implications for the ways such animals are 'made visible'. A focus on individual animals offers considerable potential to engage and mobilise wider human interest, in a similar way to the fictional literature and film examples previously cited. There is a danger that the focus on individuals could be interpreted highly anthropomorphically. However, if approached sensitively, such studies might help humans to engage and empathise more closely with the pressures and problems faced by the individual in question, offering an alternative perspective to the often quantitative discussions of, for instance, collapsing global fish stocks.

Engaging the individual is, then, part of a wider ethical and political project to move animals from the shadows. Jones $(2000,279)$ argues that individual non-humans' ethical invisibility 'has enabled humans to manipulate, exploit, displace, consume, waste and torture non-human individuals with impunity'; a focus on species and populations directs ethical concern to issues of scarcity and abundance. Re-focusing on individuals and their daily lives offers one route into examining the 'inconstancy' (ibid) of ethical practice, whilst providing a means to celebrate diversity and difference and further challenging understandings of what it means to be 'animal'. 
Bear, C. (2011), Being Angelica? Exploring individual animal geographies. Area, 43: 297304. doi: 10.1111/j.1475-4762.2011.01019.x

\section{Acknowledgements}

I am grateful to Amanda Rogers, three anonymous referees and the audience at the RGSIBG conference session on 'Wittgenstein's Lion: knowing animals in human geography research' for their insightful comments on earlier versions of this paper. I am also thankful to friends and colleagues in the Department of Geography, University of Hull, where much of the work was undertaken, to Jean Bear for introducing me to Angelica, and to Russell Hitchings for alerting me to her demise.

\section{References}

Bear C and Eden S 2011 Thinking like a fish? Engaging non-human difference through recreational angling Environment and Planning D 29

Bingham N 2006 Bees, butterflies, and bacteria: biotechnology and the politics of nonhuman friendship Environment and Planning A 38 483-98

$\begin{array}{llll}\text { Brown } & \text { C } & 2008 & \text { Environmental }\end{array}$ (http://www.thedeep.co.uk/pdf/TheDeep'sEnvironmentalPolicy.pdf) Accessed 1 July 2010

Captive Animals' Protection Society 2004 Suffering deep down: an investigation into public aquaria in the UK CAPS, Preston

Davies G 2008 Thinking, reasoning and writing with animals in the biosciences. Essay review Biosocieties 3 446-451

Derrida J 2002 The animal that therefore I am (more to follow) Critical Inquiry 28 369-418

Fox R 2006 Animal behaviours, post-human lives: everyday negotiations of the animalhuman divide in pet-keeping Social and Cultural Geography 7 525-537 
Bear, C. (2011), Being Angelica? Exploring individual animal geographies. Area, 43: 297304. doi: 10.1111/j.1475-4762.2011.01019.x

Grogan J 2005 Marley and me: life and love with the world's worst dog William Morrow, New York

Haraway D 2008 When species meet University of Minnesota Press, Minneapolis

Hinchliffe S, Kearnes M B, Degen M and Whatmore S 2005 Urban wild things: a cosmopolitical experiment Environment and Planning D: Society and Space 23 64358

Holloway L 2001 Pets and protein: placing domestic livestock on hobby-farms in England and Wales Journal of Rural Studies 17 293-307

Holloway L 2007 Subjecting cows to robots: farming technologies and the making of animal subjects Environment and Planning D: Society and Space 25 1041-1060

Ingold T ed 1994 What is an animal? Routledge, London

Johnston C 2008 Beyond the clearing: towards a dwelt animal geography Progress in Human Geography 32 633-649

Jones 02000 (Un)ethical geographies of human-animal relations: encounters, collectives and spaces in Philo C and Wilbert C eds Animal Spaces, Beastly Places: New Geographies of Human-Animal Relations Routledge, London 268-91

Latour B 1993 We have never been modern Cambridge: Harvard University Press

Lorimer H 2005 Herding memories of humans and animals Environment and Planning D: Society and Space 24 497-518

Lorimer J 2010 Moving image methodologies for more-than-human geographies Cultural Geographies 17 237-258

Lovenheim P 2003 Portrait of a burger as a young calf: the story of one man, two cows, and the feeding of a nation Three Rivers Press, California 
Bear, C. (2011), Being Angelica? Exploring individual animal geographies. Area, 43: 297304. doi: 10.1111/j.1475-4762.2011.01019.x

Lulka D 2009 The residual humanism of hybridity: retaining a sense of the earth Transactions of the Institute of British Geographers 34 378-393

Malamud R 1998 Reading zoos: representations of animals and captivity Macmillan, Basingstoke

Malamud R 2007 Prologue in Kalof L and Fitzgerald A eds The animals reader Berg, Oxford ix-xi

Mather J A 1995 Cognition in cephalopods Advances in the study of behaviour 24 317-353

Maxwell G 1960 Ring of bright water Longmans, London

Midgley M 1983 Animals and why they matter: a journey around the species barrier Penguin, Harmondsworth

Mullan B and Marvin G 1987 Zoo culture Weidenfeld and Nicolson, London

Philo C 1995 Animals, geography and the city: notes on inclusions and exclusions Environment and Planning D: Society and Space 13 655-681

Philo C 2005 Spacing lives and lively spaces: partial remarks on Sarah Whatmore's Hybrid Geographies Antipode 37 824-833

Philo C and Wilbert C eds 2000 Animal spaces, beastly places: new geographies of humananimal relations Routledge, London

Power E 2008 Furry families: making a human-dog family through home Social and Cultural Geography 9 535-555

Ryan J R 2000 'Hunting with the camera': photography, wildlife and colonialism in Africa in Philo C and Wilbert C eds Animal spaces, beastly places: new geographies of human-animal relations Routledge, London 203-221 
Bear, C. (2011), Being Angelica? Exploring individual animal geographies. Area, 43: 297304. doi: 10.1111/j.1475-4762.2011.01019.x

Sanders C R 2006 "The dog you deserve" - ambivalence in the K-9 officer/patrol dog relationship Journal of Contemporary Ethnography 35 148-72

Scruton R 1996 Animal rights and wrongs Metro, London

Shapiro K J 1997 A phenomenological approach to the study of nonhuman animals in

Mitchell R W, Thompson N S and Miles L H eds Anthropomorphism, anecdotes and animals State University of New York Press, Albany 277-295

Sorenson J 2008 Monsters: the case of Marineland in Castriano J ed Animal subjects: an ethical reader in a posthuman world Wilfred Laurier University Press, Waterloo 195222

The Deep date unknown Information on funders and sponsors of The Deep http://www.thedeep.co.uk/pdf/Funders\&Sponsors.pdf

Ufkes F 1998 Building a better pig: fat profits in lean meat in Wolch J and Emel J eds Animal geographies: place, politics, and identity in the nature-culture borderlands. Verso, London 241-255

Whatmore S 2002 Hybrid geographies: natures, cultures, spaces Sage, London

Whatmore S 2005 Hybrid geographies: author's responses and reflections Antipode 37 $842-845$

Whatmore S and Thorne L 1998 Wild(er)ness: reconfiguring the geographies of wildlife Transactions of the Institute of British Geographers 23 435-454

Whatmore S and Thorne L 2000 Elephants on the move: spatial formations of wildlife exchange Environment and Planning D: Society and Space 18 185-203

Wolch J and Emel J 1995 Bringing the animals back in Environment and Planning D: Society and Space 13 632-636 
Bear, C. (2011), Being Angelica? Exploring individual animal geographies. Area, 43: 297304. doi: 10.1111/j.1475-4762.2011.01019.x

Woods M 2000 Fantastic Mr Fox? Representing animals in the hunting debate in Philo C and Wilbert C eds Animal spaces, beastly places: new geographies of human-animal relations Routledge, London 182-202

Yorkshire Forward date unknown The Deep in Hull (http://www.yorkshireforward.com/media-centre/our-success-stories/Yorkshire-Forward-funding-helps-

to-bring-over-2-million-visitors-to-Hull-since-2002) Accessed 1 July 2010 